\title{
Гуморальна реактивність до Hsp60, міозину та Sgt1 сироватки новонароджених із вродженими вадами серця
}

\author{
Воробйова Г. М. ${ }^{1}$, Яковенко Л. Ф. ${ }^{2}$, Ткаченко Я. В. ${ }^{1}$, Бобик В. І. ${ }^{2}$, Сидорик Л. Л. ${ }^{2}$ \\ ${ }^{1}$ ДУ «Науково-практичний медичний центр дитячої кардіології та кардіохірургії МОЗ України» (Київ) \\ ${ }^{2}$ Інститут молекулярної біології та генетики НАН України (Київ)
}

\begin{abstract}
На сьогодні у клініці використовується багато кардіологічних біомаркерів, найчастіше - натрійуретичні пептиди та тропоніни, багато інших знаходяться в розробці. Нами показано доцільність визначення рівнів антитіл проти білка теплового шоку 60 (heat shock protein 60, Hsp60) у сироватці як маркера безпечності та ефективності використання аутологічної пуповинної крові в кардіохірургії новонароджених із критичними вродженими вадами серця.

Мета роботи - порівняльне дослідження гуморальної реактивності до Hsp60, міозину та Sgt1 сироватки новонароджених із критичною вродженою вадою серця, яким під час хірургічної корекції вродженої вади переливали аутологічну пуповинну кров або компоненти донорської крові, у динаміці.

Матеріали та методи досліджень. Обстежено 102 новонароджених із транспозицією магістральних судин: група 1 - 42 пацієнти, яким під час хірургічної операції переливали аутологічну пуповинну кров; група 2 48 пацієнтів, яким під час операції переливали компоненти донорської крові. Контрольну групу склав 21 клінічно здоровий новонароджений. Рівень IgG антитіл проти Hsp60, міозину людини та Sgt1 у сироватці визначали методом ІФА.

Результати досліджень. У ранньому післяопераційному періоді у пацієнтів групи 1 не спостерігалося зростання рівнів анти-Hsp60 та анти-Sgt1 антитіл, навпаки, відбувалося їх зниження. У пацієнтів групи 2 в ранньому післяопераційному періоді виявлено зростання рівнів анти-Hsp60 антитіл та анти-Sgt1 антитіл у 12,5\% (6/48) випадків. У віддаленому післяопераційному періоді підвищені рівні анти-Hsp60 та анти-Sgt1 антитіл виявлялися лише у пацієнтів із вродженою вадою, яким під час хірургічної корекції переливали компоненти донорської крові, у той час як антитіла проти міозину детектувалися з однаковою частотою $22,2 \%(6 / 27)$ та 23,3\% (7/30) у пацієнтів обох груп.

Висновки. У віддаленому післяопераційному періоді підвищені рівні анти-Hsp60 та анти-Sgt1 антитіл виявлялись лише у пацієнтів із вродженою вадою серця, яким під час хірургічної корекції переливали компоненти донорської крові. Застосування компонентів донорської крові у новонароджених із вродженою вадою серця під час операції, на відміну від аутологічної пуповинної крові, може призводити до розвитку аутоімунних процесів в організмі пацієнта у віддаленому періоді після операції.
\end{abstract}

Ключові слова: анти-Нsр60 антитіла, антитіла проти міозину, анти-Sgt1 антитіла, аутологічна пуповинна кров, критичні вроджені вади серия.

На сьогодні у клініці використовується багато кардіологічних біомаркерів, серед них найчастіше - натрійуретичні пептиди та тропоніни, багато інших маркерів знаходяться в розробці [1].

Раніше нами було показано доцільність визначення рівнів антитіл проти білка теплового шоку 60 (heat shock protein 60, Нsp60) у сироватці крові як маркера безпечності та ефективності використання аутологічної пуповинної крові в кардіохірургії новонароджених iз критичними вродженими вадами серця (BВC) [2].

Нsp60 - мітохондріальний шаперонін, виявляється також у цитоплазмі. Під час стресу, в тому числі при хірургічному втручанні, Нsp60 експресується на клітинній мембрані і/або секретується в позаклітинний простір і циркуляцію. Вважається, що позаклітинний
Нsp60 здатен опосередковувати аутоімунну агресію проти стресованих клітин та індукувати розвиток захворювання [3, 4].

Міозини - суперродина білків, які зв'язують актинові філаменти і забезпечують скорочувальну здатність міофібрили та рухливість клітини, регулюють форму клітини, беруть участь у клітинному сигналінгу тощо. Міозин міокарда - один з найбільших білків в організмі, складається з 6 поліпептидних ланцюгів, має молекулярну масу близько 500 кДа. Встановлена наявність спільних епітопів між молекулами важких ланцюгів міозину та Нsp60 людини [5].

Sgt1 - білок, що бере участь у регуляції клітинного циклу, Нsp90-опосередкованій протеасомній деградації білків. Білковий комплекс Sgt1, його білок-мішень 
RAR1 та Hsp90 модулює активність і стабільність певних компонентів сигнальних шляхів, що забезпечують резистентність організму до патогенів. Білками-мішенями для Sgt1 є білки родини S100 (S100A6, S100B, $\mathrm{S} 100 \mathrm{P})$, які беруть участь у багатьох $\mathrm{Ca}^{2+}$-залежних клітинних процесах (клітинний ріст і диференціація, транскрипція, захист від оксидативного ушкодження клітини тощо) [6].

Мета даної роботи - визначення гуморальної реактивності сироватки до Hsp60, міозину та Sgt1 у новонароджених із критичною ВВС, яким під час хірургічної корекції переливали аутологічну пуповинну кров та компоненти донорської крові, у динаміці.

Матеріали та методи. Обстежено 102 новонароджених із транспозицією магістральних судин (ТМС): група 1 - 42 пацієнти, яким під час хірургічної операції з використанням апарату штучного кровообігу переливали аутологічну пуповинну кров, операція проводилась у перші 2-6 годин після народження; група 2 - 48 пацієнтів, яким під час операції переливали компоненти донорської крові, операція проводилась через 3-8 днів після народження. Контрольну групу склав 21 клінічно здоровий новонароджений.

Рівень IgG антитіл проти Нsp60, міозину людини та Sgt1 у сироватці визначали методом IФА. Як антиген використовували рекомбінантний білок GroEL Escherihia coli (прокаріотний гомолог Нsp60 людини). Одержання та очистку рекомбінантного білка GroEl E.coli проводили за розробленою методикою [7]. Препарати міозину отримували з біопсійного матеріалу лівого шлуночка здорової людини, яка трагічно загинула [8]. Рекомбінантний білок Sgt1 люб'язно наданий професором Г. Філіпе (Інститут експериментальної біології ім. проф. Ненського, Варшава, Польща). Антитілопозитивною вважали сироватку, оптична густина якої у розведенні 1:50 перевишувала середнє значення оптичної густини на 2 стандартні відхилення $(\mathrm{m}+2 \mathrm{sd})$. Як позитивний контроль використовували одержані нами поліклональні антитіла проти рекомбінантного GroEL та Sgt1.

Дослідження рівнів антитіл проводили в динаміці - до операції та у віддалений період (3, 6, 12 місяців, 1 рік 6 місяців та 2 роки). Усі досліджувані зразки сироватки було проскриновано на наявність антитіл класу IgG одночасно (3-6 відтворюваних повторів), у роботі представлено результати останньої постановки.

Вестерн-блотинг (імуноблотинг) проводили за стандартною методикою, використовували одержані нами поліклональні анти-Нsp60 антитіла.

Статистичну обробку результатів досліджень здійснювали за допомогою пакету програм STATISTICA 8.0 (Stat-Soft, 2007, США). Для порівняння вибірок досліджуваних груп використовували U-критерій Манна-Уїтні (Mann-Whitney U-test).

Результати та обговорення. Встановлено, що до операції у пацієнтів 1-ї групи рівень антитіл проти Нsp60 та міозину був вищим за норму в $14,28 \%$ (6/42) та 7,14\% (3/42) новонароджених відповідно, рівень анти-Sgt1 антитіл знаходився в межах норми. У пацієнтів 2-ї групи рівень антитіл проти всіх досліджуваних білків був вищим за норму в 20,8\% (10/48), 4,2\% (2/48) та 8,3\% (4/48) випадків відповідно.

У ранньому післяопераційному періоді у пацієнтів 1-ї групи не спостерігалося зростання рівнів антиHsp60 антитіл, а навпаки, відбувалося їх зниження. За критерієм Wilcoxon виявлено зниження вмісту IgG анти-Нsp60 антитіл у сироватці крові пацієнтів 1-ї групи після операції порівняно з доопераційним періодом ( $\mathrm{p}=0,00009$ - 1-ша доба; $\mathrm{p}=0,014-3$-тя доба; $\mathrm{p}=0,005-7$-а доба). Встановлено обернену кореляцію між рівнем анти-Нsp60 антитіл у сироватці та об’ємом аутологічної пуповинної крові, перелитої пацієнту під час операції (3-тя доба $-\mathrm{r}=-0,39)$.

У 66,7\% (32/48) пацієнтів 2-ї групи сироватка була анти-Нsp60 негативною протягом усього періоду спостереження (1-ша підгрупа), у 20,8\% (10/48) - антиHsp60-позитивна сироватка детектувалась як до операції, так і в ранньому післяопераційному періоді (2-а підгрупа), у решти 12,5\% (6/48) пацієнтів анти-Hsp60 позитивна сироватка виявлялася лише в післяопераційному періоді (3-тя підгрупа). За критерієм Wilcoxon, у 35,4\% (17/48) пацієнтів 2-ї групи встановлено зростання рівнів досліджуваного показника в ранній післяопераційний період ( $\mathrm{p}=0,00001)$. Виявлено пряму кореляцію між об'ємом перелитої донорської плазми та рівнем анти-Нsp60 антитіл у новонароджених із ТМС ( 1 -ша доба $-\mathrm{r}=0,37 ; 3$-тя доба $-\mathrm{r}=0,4 ; \mathrm{p}<0,05)$, а також між об'ємом перелитої донорської плазми та терміном перебування новонароджених із ТМС у стаціонарі $(\mathrm{r}=0,54, \mathrm{p}<0,05)$.

На рис. 1 представлено результати графічного аналізу деяких клінічних показників у пацієнтів 1-ї та 2-ї групи. Відсоток пацієнтів, які перебуваливу реанімації більше 7 діб, у стаціонарі - більше 20 днів, курс антибіотикотерапії у яких перевищував 5 днів, був найвищим у 3-й підгрупі 2-ї групи (анти-Hsp60 позитивна сироватка виявлялась лише в післяопераційний період), найнижчим - у пацієнтів 1-ї групи. Встановлено, що гіпертермія у пацієнтів 1-ї групи спостерігалась до 9 діб, у пацієнтів 2-ї групи - до 17 діб максимально. За даними температурного листа найвища температура тіла у пацієнтів 1-ї групи становила $37,9 \mathrm{C}^{\circ}$; у пацієнтів 2-ї групи - 38,9 $\mathrm{C}^{\circ}$. У частини пацієнтів 2-ї групи в ранньому післяопераційному періоді мали місце ускладнення з боку органів дихальної системи. Більше 20 днів у стаціонарі перебував лише один пацієнт 1-ї групи (21 день) і майже половина (23/48) пацієнтів 2-ї групи.

Через 1 рік після операції у пацієнтів 1 групи антиНsp60-позитивну сироватку виявлено у 5\% (1/20) обстежених пацієнтів. Через 2 роки всі досліджувані зразки сироватки пацієнтів 1-ї групи були анти-Hsp60- 


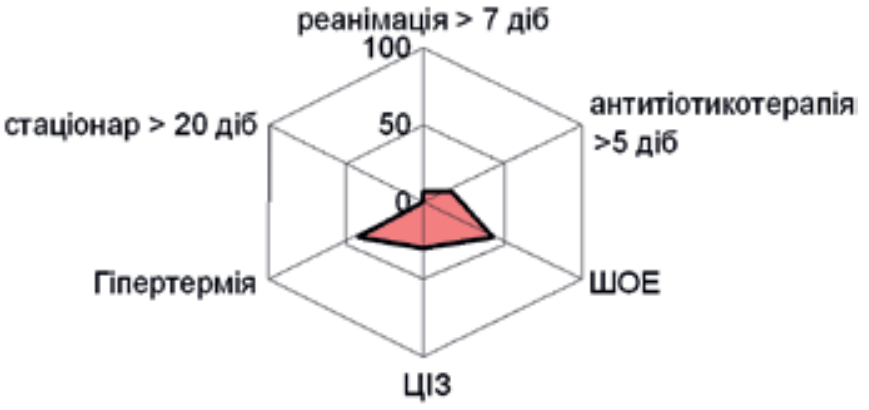

1 група

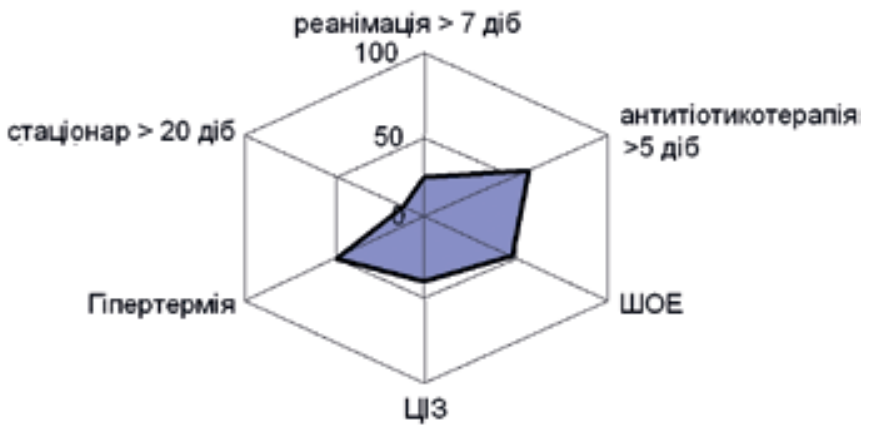

2 група, 1 підгрупа

(анти-Нsp60-негативна сироватка до та після операції)

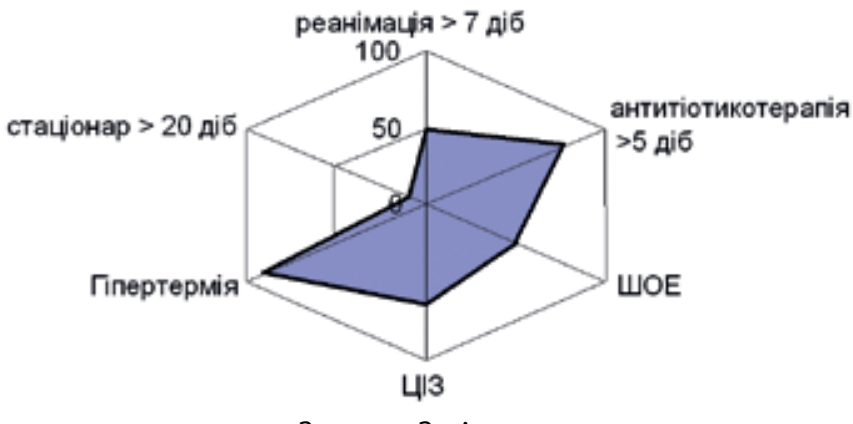

2 група, 2 підгрупа

(анти-Нsp60-позитивна сироватка до та після операції)

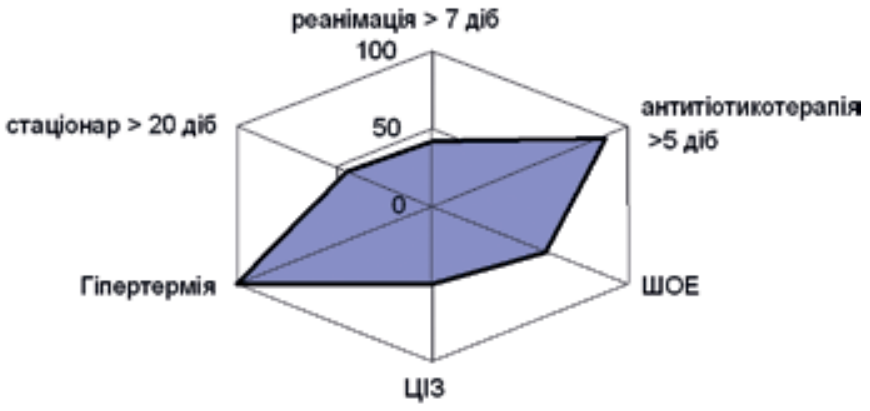

2 група, 3 підгрупа

(анти-Нsp60-позитивна сироватка після операції)
Рис. 1. Графічний аналіз клінічних показників у новонароджених із вродженою вадою серия, яким під час хірургічної операції переливали аутологічну пуповинну кров або компоненти донорської крові. Чим більша площа заштрихованої фігури, тим більший процент пацієнтів перебував у реанімації понад 7 діб, у стаціонарі понад 20 діб, тривалість антибіотикотерапії перевищувала 5 діб тощо

негативними. У пацієнтів 2-ї групи через 1 рік після операції анти-Нsp60-позитивну сироватку виявлено у $7,1 \%(1 / 14)$ обстежених, через 2 роки - у 20\% (2/10).

Як зазначалося вище, Нsp60 та міозин міокарда мають спільні епітопи. За результатами Вестерн-блотингу анти-Нsp60 антитіла розпізнавали як власний антиген (Нsp60), так і важкі ланцюги міозину. Отже, анти-Нsp60 антитіла здатні чинити додатковий ушкоджуючий вплив на клітини міокарда за рахунок перехресної реактивності (механізм молекулярної мімікрії) (рис. 2).

У ранньому післяопераційному періоді не було виявлено анти-Sgtl-позитивної сироватки у пацієнтів 1-ї групи. Або детектувалось зниження рівнів досліджуваних антитіл, або вони залишались незмінними протягом усього періоду спостереження (2 роки). За критерієм Wilcoxon виявлено зниження рівнів анти-Sgt1 антитіл на 1-шу добу після операції порівняно з доопераційним періодом $(\mathrm{p}=0,002)$, на 7-му добу порівняно з 1-ю добою $(\mathrm{p}=0,0068)$.

У пацієнтів 2-ї групи спостерігалась інша картина. У ранньому післяопераційному періоді підвищення рівнів анти-Sgt1 антитіл (анти-Sgt1-позитивна сироватка) детектувалось у 12,5\% (6/48) пацієнтів, у віддаленому післяопераційному періоді - у 37,5\% (18/48) пацієнтів. За критерієм Wilcoxon встановлено підвищення рівнів досліджуваних антитіл через 3 та 6 місяців після операції порівняно з 1-ю добою після операції ( $\mathrm{p}=0,03$ та $\mathrm{p}=0,02$ відповідно). Виявлено статистично значущу різницю рівнів анти-Sgt1 антитіл між

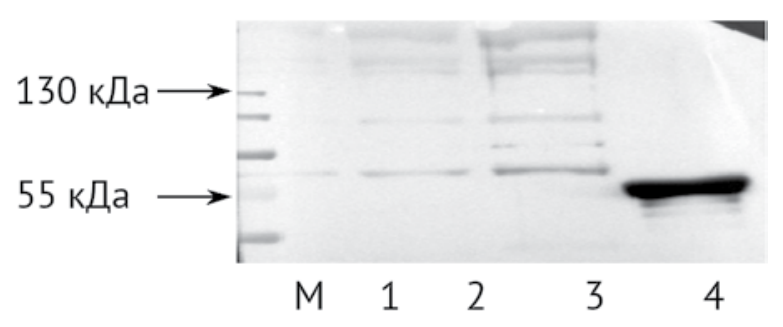

Рис. 2. Перехресна реактивність поліклональних антиНsp60 антитіл за результатами Вестерн-блотингу:

М - маркер; 1-3 - міозин (2, 4, 6 мкг/доріжку); 4 - рекомбінантний Нsp60 людини (2 мкг/доріжку) 
пацієнтами 1-ї та 2-ї групи (1-ша доба $-\mathrm{p}=0,000001$, 7-ма доба $-p=0,000001,6$ місяців $-p=0,00028,1$ рік $-\mathrm{p}=0,022)$. Слід зазначити, що у віддаленому післяопераційному періоді підвищений рівень анти-Hsp60 антитіл та анти-Sgt1 антитіл спостерігався в одних і тих самих пацієнтів, яким переливали компоненти донорської крові.

За результатами проведених досліджень, у віддаленому періоді після операції (2 роки) у пацієнтів обох обстежених груп антитіла проти міозину виявлялися 3 однаковою частотою $(22,2 \%(6 / 27)$ та $23,3 \%(7 / 30)$ відповідно), що може бути наслідком хірургічного втручання.

Антитільний профіль новонародженої дитини визначають IgG антитіла, здатні проникати через плаценту. Рівень антитіл, одержаних від матері, починає знижуватися з 3-місячного віку дитини. Самостійно дитина здатна продукувати низькі рівні власних антитіл у періоді між 3 та 6 місяцем до народження, і представлені вони антитілами класу IgM. Рівні власних IgG починають зростати вже після народження. Отже, IgG антитіла проти досліджуваних нами антигенів, що виявлялись у сироватці дітей із ТМС у віддаленому періоді, можна вважати їх власними. Підвищені рівні анти-Hsp60, анти-Sgt1 антитіл у пацієнтів 2-ї групи у віддаленому періоді може свідчити про наявність в організмі аутоімунних процесів.

Таким чином, результати проведених нами досліджень свідчать про можливість розвитку аутоімунних процесів у віддаленому періоді у новонароджених із TMC, яким під час хірургічної корекції вродженої вади серця переливали компоненти донорської крові.

Висновки. У пацієнтів із ТМС, яким переливали аутологічну пуповинну кров, або спостерігалось зниження рівнів анти-Нsp60 та анти-Sgt1 антитіл у сироватці, або вони знаходилися в межах норми протягом усього періоду спостереження (2 роки).

У віддаленому післяопераційному періоді підвищені рівні анти-Hsp60 та анти-Sgt1 антитіл виявля- лися лише у пацієнтів із ТМС, яким під час хірургічної корекції вродженої вади переливали компоненти донорської крові, антитіла проти міозину виявлялись з однаковою частотою в пацієнтів обох обстежених груп.

Застосування компонентів донорської крові у новонароджених із ТМС під час операції на серці, на відміну від використання аутологічної пуповинної крові, може призводити до розвитку аутоімунних процесів в організмі пацієнта у віддаленому періоді після операції.

\section{Лiтература}

1. Use of cardiac biomarkers in neonatology / Vijlbrief D., Benders M., Kemperman H. et al. /// Pediatr. Res. 2012. - Vol. 72, N 4. - P. 37-43.

2. Застосування анти-Нsp60 антитіл як маркерів імунної безпеки проведення гемотрансфузій у кардіохірургії вроджених вад серця / Ткаченко Я. В., Воробйова Г. М., Сидорчик Л. Л. та ін. // Патент на винахід №103141. Опубл. 10.09.2013, Бюл. № 17.

3. Chlamydya trachomatis infection and anti-Hsp60 immunity: the two sides of the coin / Cappello F., de Macario E., Di Felice V. et al. |// Plos Pathogens. 2009. - Vol.5, N 8. - P. 1-9.

4. Cross-reactive B-cell epitopes of microbial and human heat shock protein 60/65 in atherosclerosis / Perschinka H., Mayr M., Millonig G. et al. |// Arteriscler. Thromb. Vasc. Biol. - 2003. - Vol. 23, N 6. - P. 1060-1065.

5. Shoenfeld Y., Gershwin M., Meroni P. Antibodies. - 2007 (Elsevier). $-830 \mathrm{p}$.

6. Spiechowicz M., Filipek A. The expression and function of Sgt1 protein in eukaryotic cells // Acta Neurobiol. Exp. 2005. - Vol. 65. - P. 161-165.

7. Получение рекомбинантного шаперона GroEL и его иммунологическая кросс-реактивность с Hsp60 / Капустян Л., Кия мова Р., Гришкова В. и др. // Biopolym. Cell. - 2006. - Vol. 22, N 2. - P. 117-121.

8. Розробка експериментальної моделі аутоімунного міозин-індукованого пошкодження міокарда / Бобик В., Рябенко Д., Сергієчко О. та ін. // Biopolym. Cell. - 2007. - Vol. 23, N 2. - P. 115-121.

\title{
Humoral reactivity to Hsp60, miosyn and Sgt1 of the sera of newborns with complex congenital heart defect
}

\author{
Vorobyova G. M. ${ }^{1}$, Yakovenko L. F. ${ }^{2}$, Tkachenko Y. V. ${ }^{1}$, Bobyk V.I. ${ }^{2}$, Sidoryk L. L. ${ }^{2}$ \\ ${ }^{1}$ Ukrainian Children's Cardiac Center (Kyiv) \\ ${ }^{2}$ Institute of Molecular Biology and Genetics NAS of Ukraine (Kyiv)
}

Currently, many cardiac biomarkers are used in the clinic, including natriuretic peptides and troponins, and many others are under development. The expediency of determining levels of antibodies against heat shock protein 60 (Hsp60) in serum as a safety and effectiveness marker of the autologous cord blood usage in cardiac surgery of infants with the critical congenital heart defect was shown.

Purpose. A comparative study of humoral reactivity to Hsp60, myosin, and Sgt1 of infant's serum with critical congenital heart disease, which received the transfusion of autologous cord blood or donor blood components during surgical correction of congenital heart. 
Materials and methods. 102 infants with transposition of great arteriies were studied: group $1-42$ patients who received the transfusion of autologous cord blood during the surgery; group 2-48 patients who received the transfusion of donor blood components during the surgery. The control group included 21 clinically healthy newborns. The level of IgG antibodies against Hsp60, human myosin, and Sgt1 in serum was determined by ELISA.

Results. It was observed that levels of anti-Hsp60 and anti-Sgt 1 antibodies did not increase, but rather decrease in the early postoperative period in patients of group 1 . In group 2 patients in the early postoperative period revealed increasing levels of anti-Hsp60 antibody and anti-Sgt1 antibodies in 12,5\% (6/48) of cases. In the remote postoperative period, elevated levels of anti-Hsp60 and anti-Sgt1 antibodies were identified only in patients with a congenital defect, which received the blood transfusion of donor's blood components during surgical correction while antibodies against myosin we detected equally in patients of both groups $(22,2 \%(6 / 27)$ and $23,3 \%(7 / 30)$ respectively).

Conclusion. In the remote postoperative period ( 2 years), elevated levels of anti-Hsp60 and anti-Sgt 1 antibodies were identified only in patients with congenital heart defect, which received the transfusion of donor blood components during surgical correction. The use of donor blood components in a newborn with a congenital heart defect during the surgery, as opposed to autologous cord blood can lead to the development of autoimmune processes in the patient in the remote period after surgery.

Key words: anti-Hsp60 antibodies, antibodies to miosyn, anti-Sgt1 antibodies, autologic umbilical cord blood, complex congenital heart defect.

\title{
Гуморальная реактивность к Нsp60, миозину и Sgt1 сыворотки новорожденных с врожденными пороками сердца
}

\author{
Воробьева А. М. ${ }^{1}$, Яковенко Л. Ф. ${ }^{2}$, Ткаченко Я. В. ${ }^{1}$, Бобык В. И. ${ }^{2}$, Сидорик Л. Л. ${ }^{2}$ \\ ${ }^{1}$ ДУ «Научно-практический медицинский центр детской кардиологии и кардиохирургии МЗ Украины» (Киев) \\ ${ }^{2}$ Институт молекулярной биологии и генетики НАН Украины (Киев)
}

На сегодняшний день в клинике используются многие кардиологические биомаркеры, чаще всего - натрийуретические пептиды и тропонины, многие другие находятся в разработке. Нами показана целесообразность определения уровня антител к белку теплового шока 60 (heat shock protein 60, Hsp60) в сыворотке крови как маркера безопасности и эффективности использования аутологичной пуповинной крови в кардиохирургии новорожденных с критическими врожденными пороками сердца.

Цель работы - сравнительное исследование гуморальной реактивности к Hsp60, миозину и Sgt1 сыворотки новорожденных с критическим врожденным пороком сердца, которым во время хирургической коррекции переливали аутологичную пуповинную кровь или компоненты донорской крови.

Материалы и методы исследования. Обследовано 102 новорожденных с транспозицией магистральных сосудов: 1-я группа - 42 пациента, которым во время хирургической операции переливали аутологичную пуповинную кровь; 2-я группа - 48 пациентов, которым во время операции переливали компоненты донорской крови. Контрольную группу составил 21 клинически здоровый новорожденный. Уровень IgG антител к Hsp60, миозину человека и Sgt1 в сыворотке определяли методом ИФА в динамике.

Результаты исследований. В раннем послеоперационном периоде у пациентов 1-й группы не наблюдалось роста уровней анти-Hsp60 и анти-Sgt1 антител, а наоборот, отмечено их снижение. У пациентов 2-й группы в раннем послеоперационном периоде уровни анти-Hsp60 антител и анти-Sgt1 антител возрастали в 12,5\% (6/48) случаев. В отдаленном послеоперационном периоде повышенные уровни анти-Hsp60 и анти-Sgt1 антител выявлялись только у пациентов с врожденным пороком сердца, которым во время хирургической коррекции переливали компоненты донорской крови. Антитела к миозину определялись у пациентов обеих групп с одинаковой частотой $(22,2 \%(6 / 27)$ и $23,3 \%(7 / 30)$ соответственно).

Выводы. В отдаленном послеоперационном периоде повышенные уровни анти-Hsp60 и анти-Sgt1 aнтител выявлялись только у пациентов с врожденным пороком сердца, которым во время хирургической коррекции переливали компоненты донорской крови. Применение компонентов донорской крови у новорожденных с врожденным пороком сердца во время операции, в отличие от использования аутологичной пуповинной крови, может приводить к развитию аутоиммунных процессов в организме пациента в отдаленном периоде после операции.

Ключевые слова: анти-Нsp60 антитела, антитела против миозина, анти-Sgt1 антитела, аутологичная пуповинная кровь, критические врожденные пороки сердиа. 